\title{
Coronavirus Disease 2019 (Covid-19) Dampak Covid-19 Terhadap Masyarakat Comorbid Dan Perekonomian Masyarakat Di Desa Dukuhwaluh, Kecamatan Kembaran, Kabupaten Banyumas
}

\section{Coronavirus Disease 2019 (COVID-19) The Effect of Covid-19 on Comorbid Community and the Community Economy in Dukuhwaluh Village, Kembaran District, Banyumas Regency}

\author{
Anisa Ika Marliana ${ }^{1}$, Amara Auliafani ${ }^{2}$, Rama Wahyu Prasetyo ${ }^{3}$, Bunga Olivia ${ }^{4}$, Cinthia Dewi \\ $1,2,3,4,5$ Geography Education, Teacher Training and Education Faculty, Universitas Muhammadiyah Purwokerto
}

\section{ARTICLE INFO}

Article history:

DOI:

10.30595/pssh.v1i.89

Submited:

April 12, 2021

Accepted:

June 10, 2021

Published:

June 14, 2021

Keywords:

Comorbid,

Perekonomian Masyarakat

\begin{abstract}
Coronavirus disease 2019 (COVID-19) is a viral pneumonia disease that first spread in Wuhan, China, in December 2019. People with comorbid diseases are one of the groups that are very vulnerable to exposure to the virus during the Covid-19 pandemic. Some accompanying diseases include hypertension, diabetes mellitus and heart disease. The impact on the economic sector in Indonesia as a result of this pandemic include layoffs, decreased imports, and rising prices (inflation). In the midst of the Covid-19 pandemic, students of Geography Education of Muhammadiyah University of Purwokerto contributed to help ease the economic burden of the people of Dukuhwaluh Village by providing social assistance. The method used in this activity is a questionnaire to find out the comorbid suffered as well as the decline of the respomden economy. Previously, students were assisted by a special team of Dukuhwaluh Village in selecting community data that has comorbid. As many as 30 people who have congenital diseases that are vulnerable to Covid-19. Based on the data obtained, the most common comorbid suffered by the community is hypertension.
\end{abstract}

This work is licensed under a Creative Commons Attribution 4.0 International License.

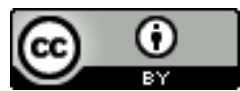

Corresponding Author:

Anisa Ika Marliana

Department of Geography Education

Teacher Training and Education Faculty, Universitas Muhammadiyah Purwokerto

Jl. KH. Ahmad Dahlan, Dukuhwaluh, Kembaran, Banyumas, Jawa Tengah, Indonesia.

Email: anisaika76@gmail.com

\section{PENDAHULUAN}

Pada akhir tahun 2019 tepatnya pada bulan desember, dunia dihebohkan dengan sebuah kejadian yang diduga sebuah kasus pneumonia yang etiologinya tidak diketahui yang kasus tersebut berasal dari Kota Wuhan, China. China mengidentifikasi pneumonia tersebut pada tanggal 7 Januari 2020 sebagai jenis baru coronavirus. Virus ini menunjukkan penyebaran yang sangat signifikan cepat dan telah banyak kematian yang disebabkan dari virus ini baik di China maupun di Negara lain sehingga pada tanggal 30 Januari 2020 WHO menetapkan virus corona ini sebagai Kedaruratan Kesehatan Masyarakat yang Meresahkan Masyarakat (Public Health Emergency of International Concern). Pada tanggal 11 Maret 2020, WHO mengumumkan bahwa wabah yang sedang terjadi saat ini sebagai Pandemic Global.

Masyarakat dengan penyakit penyerta (komorbid) merupakan salah satu kelompok yang sangat rentan terpapar virus di masa pandemi COVID-19 (Yamali, Fakhrul Rozi, and Ririn Noviyanti Putri : 2020). Beberapa penyakit penyerta diantaranya yaitu hipertensi, diabetes melitus dan penyakit jantung. Oleh karena itu, pemerintah 
melalui Kementerian Kesehatan memberikan perhatian serius dan khusus, dikarenakan orang tersebut bila terkonfirmasi COVID-19 berpotensi besar mengalami perburukan klinis sehingga meningkatkan risiko kematian (Larasati, Dwi : 2021). Masyarakat komorbid di Desa Dukuhwaluh didominasi oleh masyarakat lanjut usia dengan komorbid hipertensi. Hipertensi merupakan salah satu penyakit tidak menular yang terjadi bila tekanan sistoliknya $\geq$ $140 \mathrm{mmHg}$ dan tekanan diastolik $\geq 90 \mathrm{mmHg}$. Hipertensi seringkali tidak menimbulkan gejala sehingga merupakan penyebab terbesar dari ketidakpatuhan melaksanakan pengobatan. Oleh karena itu, Kepala Desa Dukuhwaluh membentuk tim khusus untuk melakukan pemantauan kesehatan rutin masyarakat komorbid agar tidak terinfeksi coronavirus (Alfad, Haekal, Fitria Saftarina, and Betta Kurniawan : 2021).

Selain memberikan dampak negatif bagi penderita komorbid, COVID-19 juga menurunkan penghasilan masyarakat Desa Dukuhwaluh. Dengan munculnya Covid-19 pemerintah Indonesia mulai menegaskan bahwa masyarakat di himbau untuk tidak melakukan aktivitas di luar rumah upaya untuk menghindari meningkatnya penyebaran Covid-19. Berbeda dengan negara lain yang melakukan lockdown, pemerintah Indonesia dengan kebijakan social distancing dan PSBB atau Pembatasan Sosial Berskala Besar diharapkan dapat mengurangi dampak krisis ekonomi (Farokhah, Laely, dkk : 2020).

Adanya COVID-19, pendapatan masyarakat Desa Dukuhwaluh menurun jauh dibanding dengan sebelum adanya COVID-19. Masyarakat Desa Dukuhwaluh sebagian besar merupakan pekerja swasta yang mendapat penghasilan harian. Dengan melihat keadaan masyarakat sekitar Universitas Muhammadiyah Purwokerto, mahasiswa Pendidikan Geografi melaksanakan acara bakti sosial dengan sasaran utama masyarakat Desa Dukuhwaluh yang memiliki penyakit penyerta. Pelaksanaan acara in dibantu oleh tim Desa Dukuhwaluh untuk memilah masayarakat yang memiliki penyakit penyerta.

\section{METODE PENELITIAN}

Kegiatan ini diadakan pada tanggal 4 Februari 2021, di Desa Dukuhwaluh, Kecamatan Kembaran, Kabupaten Banyumas yang dilakukan dengan memberikan bantuan sosial berupa sembako kepada masyarakat komorbid. Pelaksana kegiatan ini berharap agar bantuan yang mereka berikan kepada masyarakat Desa Dukuhwaluh dapat dimanfaatkan dengan benar, dapat membantu meringankan beban masyarakat untuk memenuhi kebutuhan hidup sehari-hari dan dapat benar-benar diberikan kepada masyarakat yang sangat membutuhkan (tepat sasaran).

Sasaran utama dalam kegiatan ini adalah masyarakat komorbid di Desa Dukuhwaluh. Pemberian bantuan sosial dilakukan dengan mengunjungi masing-masing tempat tinggal masyarakat dengan tetap menerapkan protokol kesehatan seperti penggunaan masker, menjaga jarak, tidak saling bersentuhan dan selalu membawa hand sanitizer bagi pelaksana kegiatan. Metode yang digunakan adalah metode angket. Ketika memberikan bantuan kepada masyarakat, pelaksana memberikan angket yang kemudian diisi oleh masyarakat. Setelah semua angket terkumpul, kita dapat mengetahui bagaimana dampak covid-19 bagi masyarakat Desa Dukuhwaluh dan penyakit penyerta apa saja yang diderita masyarakat Desa Dukuhwaluh.

\section{HASIL DAN PEMBAHASAN}

Hasil penelitian mengungkapkan bahwa penyakit penyerta yang banyak dialami oleh masyarakat Desa Dukuhwaluh adalah penyakit hipertensi. Diagram 1 merupakan data penyakit penyerta yang diderita masyarakat Desa Dukuhwaluh.

Diagram 1. Data Komorbid Masyarakat Desa Dukuhwaluh

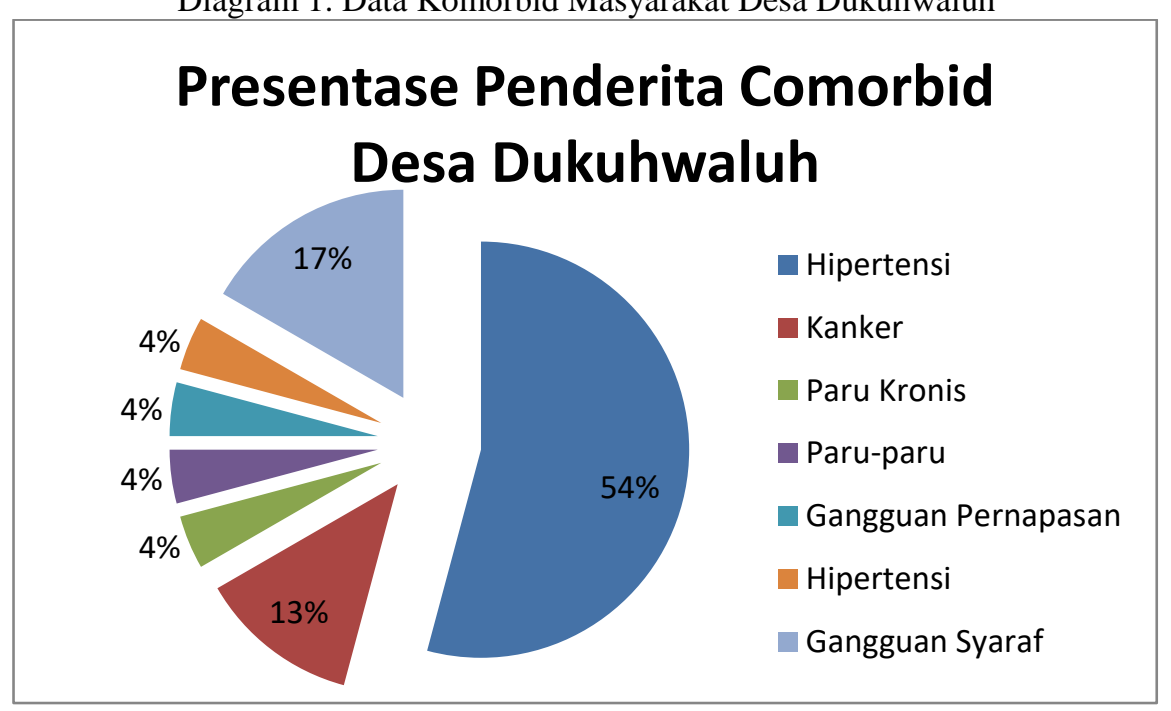


Kegiatan ini merupakan salah satu bentuk pengabdian mahasiswa kepada masyarakat terdampak COVID-19 yang ada di sekitar lingkungan Universitas Muhammadiyah Purwokerto yaitu di Desa Dukuhwaluh, Kecamatan Kembaran, Kabupaten Banyumas. Desa Dukuhwaluh terdiri atas 5 RT dan 9 RW. Jumlah penduduk Kecamatan Kembaran yaitu sebesar 81.897 jiwa. Kecamatan Kembaran termasuk dalam wilayah dataran perbukitan dengan ketinggian > 25 - 100 meter dpl. Daerah Desa Dukuhwaluh merupakan daerah yang sedang berkembang. Desa Dukuhwaluh merupakan pusat perekonomian dan pendidikan terbesar di Kecamatan Kembaran. Di Desa Dukuhwaluh terdapat perguruan tinggi muhammadiyah yaitu Universitas Muhammadiyah Purwokerto sebagai salah satu pusat pendidikan terbesar di Kabupaten Banyumas.

Di Desa Dukuhwaluh terdapat 30 masyarakat yang mempunyai penyakit bawaan yang rentan terkena Covid19, sehingga Kepala Desa Dukuhwaluh mengadakan program pemantauan kesehatan kepada masyarakat tersebut. Komorbid merupakan penyakit atau kondisi yang muncul secara bersamaan pada individu. Komorbiditas biasanya dikaitkan dengan kondisi kesehatan yang lebih buruk dan lebih kompleks. Hal ini terjadi karena terdapat gangguan episodik kronis lain atau kondisi progresif kronis lain. Gangguan ini kemudian diartikan sebagai kondisi kesehatan yang dialami oleh seseorang secara bersamaan. Gangguan yang dimaksud dapat berupa gangguan fisik maupun kejiwaan. Dalam konteks Covid-19, pasien dengan komorbid memiliki tingkat mortalitas yang lebih tinggi daripada pasien biasa. Paparan Covid-19 pada individu komorbid, seperti penderita diabetes, dapat memengaruhi paru-paru, jantung, ginjal, dan hati. Dalam sebuah penelitian, komorbid yang paling umum pada pasien Covid-19 adalah diabetes, kardiovaskular, dan penyakit sistem pernapasan. Komorbid yang diderita masyarakat Desa Dukuhwaluh yaitu hipertensi, kanker, sesak nafas, gangguan pernafasan, gangguan syaraf, paru kronis, gangguan usus halus, diabetes dan sakit kepala yang berlebih. Para penderita penyakit kronis ini biasanya memiliki imunitas yang lebih rendah dibanding orang yang sehat. Hal inilah yang membuat penderita penyakit kronis lebih rentan terpapar Covid19. Selain itu, pasien Covid-19 dengan komorbid juga memiliki risiko kematian yang lebih tinggi dibanding pasien tanpa komorbid.

Kondisi pandemi Covid-19 jelas akan mengurangi sektor konsumsi, kegiatan perjalanan dan transportasi, serta peningkatan biaya transportasi dan perdagangan. Sedangkan dari sisi penawaran, kemungkinan besar yang terjadi adalah terkontraksinya produktivitas pekerja / buruh, penurunan investasi dan kegiatan pendanaan, serta terganggunya rantai pasokan global (global value chain). Menteri Keuangan Indonesia Sri Mulyani menyebutkan pertumbuhan ekonomi berada diangka minus 0,4 persen (Rahmadia, Shinta, et al : 2020). Dampak ini juga dirasakan oleh seluruh lapisan masyarakat bahkan disemua daerah di Indonesia, begitu juga di Desa Dukuhwaluh.

Berdasarkan data yang diperoleh, komorbid yang paling banyak diderita oleh masyarakat adalah hipertensi sebanyak 54\% dari jumlah masyarakat yang memiliki penyakit penyerta. Hipertensi merupakan salah satu penyakit tidak menular yang terjadi bila tekanan sistoliknya $\geq 140 \mathrm{mmHg}$ dan tekanan diastolik $\geq 90 \mathrm{mmHg}$. Selain itu, hasil angket juga menyebutkan bahwa perekonomian masayarakat saat ini menurun jauh setelah adanya pandemi covid19 dan hingga saat ini masih belum ada perubahan menjadi lebih baik seperti keadaan sebelum adanya pandemi cobid-19.

\section{KESIMPULAN}

Desa Dukuhwaluh terdapat 30 masyarakat yang mempunyai penyakit bawaan yang rentan terkena Covid-19. Kepala Desa Dukuhwaluh membentuk tim khusus untuk memantau kesehatan masyarakat komorbid agar dapat turut serta membantu apabila terjadi penularan covid-19 pada masyarakat komorbid. Program Desa Dukuhwaluh untuk memantau kesehatan masyarakat komorbid merupakan langkah yang signifikan dan bermanfaat baik bagi desa dan masyarakat. Kegiatan yang telah kami lakukan berupa pemberian bantuan sosial sembako kepada masyarakat Desa Dukuhwaluh yang benar-benar membutuhkan bantuan sembako akibat naiknya harga kebutuhan pokok dan menurunnya perekonomian masyarakat.

\section{Ucapan Terima kasih}

The author would like to express his gratitude to Muhammadiyah University of Purwokerto for granting permission to complete this research. The author also expressed his gratitude to the Village Head and Dukuhwaluh Village Device who has provided assistance and advice during this research. The warmest gratitude and appreciation is especially given to all respondents and colleagues for being kind during the data collection process. 


\section{DAFTAR PUSTAKA}

[1] Farokhah, Laely, Yusfi Ubaidillah, and Rury Arista Yulianti. "Penyuluhan Disiplin Protokol Kesehatan Covid19 Di Kelurahan Gandul Kecamatan Cinere Kota Depok." Prosiding Seminar Nasional Pengabdian Masyarakat LPPM UMJ. Vol. 1. No. 1. 2020.

[2] Larasati, Dwi. "PENINGKATAN INFORMASI PENYAKIT DENGAN KOMORBID HIPERTENSI PADA MASA PANDEMI COVID-19 DI PUSKESMAS PIYUNGAN." ABDIMAS Madani 3.1 (2021): 21-25.

[3] Alfad, Haekal, Fitria Saftarina, and Betta Kurniawan. "Dampak Infeksi SARS-Cov-2 Terhadap Penderita Hipertensi." Jurnal Majority 9.1 (2020): 181-185.

[4] Yamali, Fakhrul Rozi, and Ririn Noviyanti Putri. "Dampak Covid-19 Terhadap Ekonomi Indonesia." Ekonomis: Journal of Economics and Business 4.2 (2020): 384-388.

[5] Rahmadia, Shinta, et al. "Dampak covid-19 terhadap ekonomi." Jurnal Ekonomi Islam (JE Islam) (2020). 